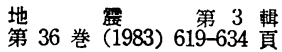

\title{
茨城県沖とその周辺海域の地震の 時空間分布と最近の活動の特徵
}

\author{
国立防災科学技術センター 野回伸 一
}

(昭和 58 年 9 月 2 日受理)

\section{Spatio-Temporal Patterns of Seismicity and Some Features of Recent Seismic Activity off Ibaraki Prefecture, Eastern Japan, and Adjacent Regions}

\author{
Shin'ichi NoguCHI \\ National Research Center for Disaster Prevention
}

(Received September 2, 1983)

\begin{abstract}
The spatio-temporal variation of seismicity and spectral characteristics of seismic waves are examined for earthquakes occurring offshore of Fukushima Prefecture, of Ibaraki Prefecture and around the Boso Peninsula, eastern Japan, on the basis of JMA earthquake data. From space-time plots of earthquakes with $M \geq 5$ and depth $\leq 60 \mathrm{~km}$ for the period from 1926 to May 1982, it is recognized that before the occurrence of the 1938 Fukushima-Oki large earthquake swarm, seismic activity became gradually high in the south of the 1938 focal area. A noticeable activity occurred in 1935 at the landward margin of the focal area of the 1938 shocks, then considerable quiescence continued till the 1938 shocks. In recent about 20 years, seismicity is admittedly low in all regions investigated. To deduce the characteristics of seismic source spectra during this inactive period, a magnitude $M_{I}$ based on seismic in tensity data is determined for a number of felt earthquakes of $M \geq 5$. The difference between $M_{I}$ and $M$ reported by JMA is used as a measure of the efficiency of the radiation of highfrequency component from the source. The temporal distribution of $M_{I}-M$ value shows a tendency of increase of the value with time in all the regions. For earthquakes off Fukushima Prefecture, $M_{I}-M$ has increased systematically since about 1965 . In the region off Ibaraki Prefecture, most earthquakes occurring about 10 years prior to July 23, 1982, IbarakiOki earthquake of $M=7$ reveal considerable large $M_{I}-M$. For earthquakes around the Boso Peninsula, $M_{I}-M$ increase gradually during the last 30 years. These large $M_{I}-M$ are mainly distributed landward of the focal area of the 1982 Ibaraki-Oki shock and in the northern part off Fukushima Prefecture, while landward and southern parts off Fukushima Prefecture have been seismically quiet of $M \geq 5$ shocks since about 1965 . It is considered that the predominance of high-frequency earthquakes in recent years is due to the extensive increase of the tectonic stress in the regions investigated. The 1982 Ibaraki-Oki earthquake of $M=7$ alone does not seem to have released this large tectonic stress, and much attention should be paied to presently inactive seismic regions adjacent to off Ibaraki Prefecture.
\end{abstract}

\section{$\S 1$. 序 論}

茨城沖は, 日本海溝沿いの浅発地震帯の中で三陸東方沖とともに群発地震活動域として特徵 昭和 57 年 4 月 10 日発表 
づけられる [MOGI (1967)]. また, 関東地方とその周辺でこの地域は定常的にも微小地震活動 が高く, 例えば, 浜田・他 (1982) の震央分布図にも著しい震央密集域として示されている. しかし，この海域では歴史上大地震は知られていない[例えば，UTSU (1974)].これに対して， 茨城沖の周辺では時おり規模 7.5 以上の大地震が発生しており, 今世紀だけをとつても，1909 年 3 月 13 日の房総半島沖地震 [宇津 (1979) のカタログで $M=7.5$; 長周期実体波マグニチュ 一ド $m_{B}=7.6, A B E$ and KANAMORI (1979)], 1923 年 9 月 1 日の関東大地震 [表面波マグニ チュード $M_{s}=8.2$, GELLER and KANAMORI (1977)], 1938 年 5 月と 11 月の福島県沖群発 地震 [全体で $M_{s}=8.1$ に相当, 辻・阿部 (1976)] そして 1953 年 11 月 26 日の房総半島沖 地震 $\left[M_{s}=7.9, \mathrm{ABE}\right.$ and KANAMORI (1980)] が挙げられる.

最近の研究結果によれば, 福島県沖から房総半島沖にかけての広い海域でこの 10 数年間な いしそれ以上地震活動は大きく低下している [茂木 (1979); UTSU (1980); 加藤・山崎・池上 (1981); 勝又・山本 (1982); 野口 (1982)]. UTSU (1980) によれば, この低活動期の $M 6$ 以上 の地震の大多数は相対的に短周期波動に富む高周波地震である. 茨城沖とその周辺海域のテク トニクプロセスを明らかにするためには，より頻ぱんに発生している規模の小さな地震の解析 も重要である.この観点から，この論文では長期間のマグニチュード 5 以上の地震資料に基づ き, 活動の推移, 時空間分布の特徵, および地震波動の低周波・高周波性の時間変化, 地域性 を解析する. そのため, 震度の観測資料を用いて新たにマグニチュードを決定し, 通常の器械 観測によるマグニチュードと比較・検討する.この解析結果に基づき, 対象地域の現在の地震 学的状沉を考察する.

\section{§2. 活動の推移}

Fig. 1 は，気象庁地震月報とその別冊第 2 号 (1966)，第 3 号 (1968) および第 6 号 (1982) による 1926 年 1982 年 5 月までの, マグニチュード 5 以上, 深さ $60 \mathrm{~km}$ 以浅の地震の震央 分布を示す. 茨城沖は, 太平洋岸の日立市・東海村付近から日本海溝の第 1 鹿島海山方向へ延 びる 4 つ程度の震央密集域からなる細長い地震帯として特徵づけられる. 海底地形の等深度線 は, 福島沖以南で海溝軸との平行性がくずれ, 特に鹿島漌沖と犬吠岬沖では水深 $2,000 \mathrm{~m}$ 以 深の凹凸が著しい。海底地形のこの不連続性は，連続音波探査の記録 [TAMAKI et al. (1977)] にも明瞭に現われている. 鹿島灘沖の海溝斜面では, 水深 $4,500 \mathrm{~m}$ 以深にベンチが見い出さ れ，その南北隣接域に比べ海溝まで緩かな傾斜構造を持つている [茂木・荻野・大島 (1980)]. 海溝付近の第 1 鹿島海山は, 比高約 $3,000 \mathrm{~m}$, 基底の直径南北に $50 \mathrm{~km}$ 東西に $30 \mathrm{~km}$ を有 し, その西半部の東側山頂に対する約 $1,500 \mathrm{~m}$ の落差は, プレート運動により二分された西 側部分の長期的な沈み込みのためと考えられている [茂木・西沢 (1980)]. この太平洋プレート とユーラシアプレートの相対運動方向は, この地域ではほぼ海溝軸に直交している [例えば, SENO and EGUCHI (1983)]. このような茨城沖の海底地形の不連続的な構造, 大規模な海山の 存在とテクトニクスは, 海溝に向かつて細長く延びたこの海域の震央分布と密接に関係してい よう. そこで, Fig. 1 のように海溝軸方向が長さ約 $300 \mathrm{~km}$, それに直交する方向約 $280 \mathrm{~km}$ の領域を, 茨城沖を中心とした三つの地域 $\mathrm{A}, \mathrm{B}, \mathrm{C}$ に区分し, 地震活動の時間变化, 時空 間分布の特徽を調べる.

Fig. 2 は, Fig. 1 の A, B, C 3 地域の $M 5$ 以上, 深さ $60 \mathrm{~km}$ 以浅の地震の 1 年毎の 


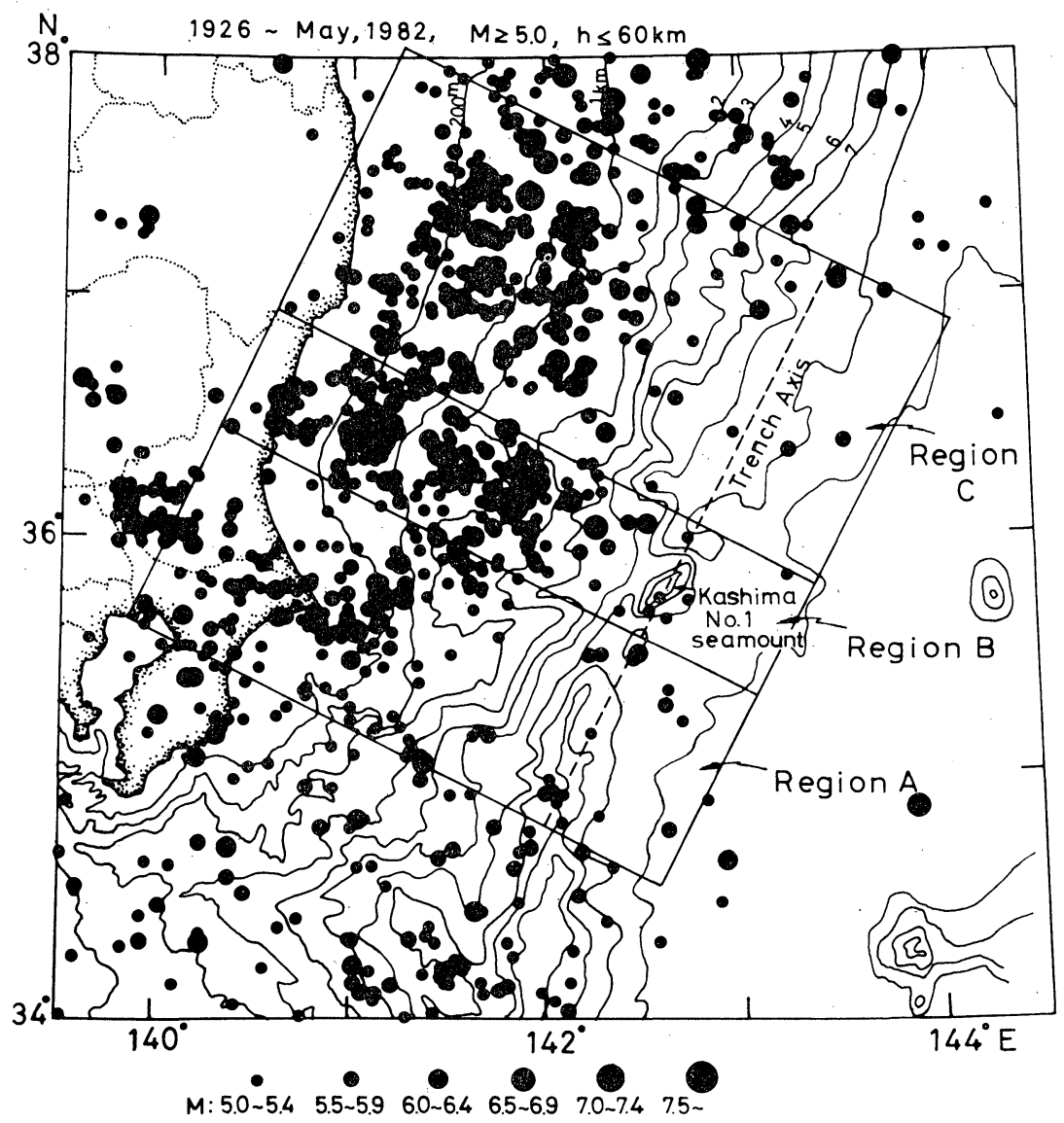

Fig. 1. Epicentral distribution of earthquakes with $M \geq 5$ and depth $\leq 60 \mathrm{~km}$ for the period from January 1926 to May 1982. Data are taken from the Seismological Bulletins of JMA. Seismicity in regions A, B and C are investigated in Figs. 2,3 and 5 .

回数を示す。 また，Fig. 3 はこれらの地震について海溝軸に平行な方向への空間・時間分布 をみたものである. これらの地域の浅発地震の規模別頻度分布の調查結果から， M5 以上の 震央はほぼもれなく決められていると思われる. Fig. 2 と Fig. 3 に基づき, 1938 年の福島 沖大群発地震活動の前と後に分けて, 3 地域の地震活動の特徵を以下にいくつか列挙する.

(1). 福島沖 (C 地域) の 1938 年の群発地震は, 対象地域・期間の中で群を抜いて大きな活 動で, 海溝軸に沿つてほぼ C 地域全域が破壊しさらに茨城沖 (B 地域)に及んでいる. $M \geq 5$ の数は 90 個にのぼり，この中には $M 7$ クラス 4 個， $M 6$ クラス. 24 個が含まれ，その多く は 1938 年 11 月に集中している [気象庁地震月報別冊第 6 号 (1982)].この 1938 年の大群発 地震の前の地震活動の特徵については, 井上 (1965) の研究があるが, ここで, この地震月報 別冊の改訂資料に基づきやや詳しい再調査を行なう。 まず，福島沖では，Fig. 2 に示される ように 1935 年にひとつの活動のピークがあるが，その後 1938 年 5 月 23 日の茨城よりの 


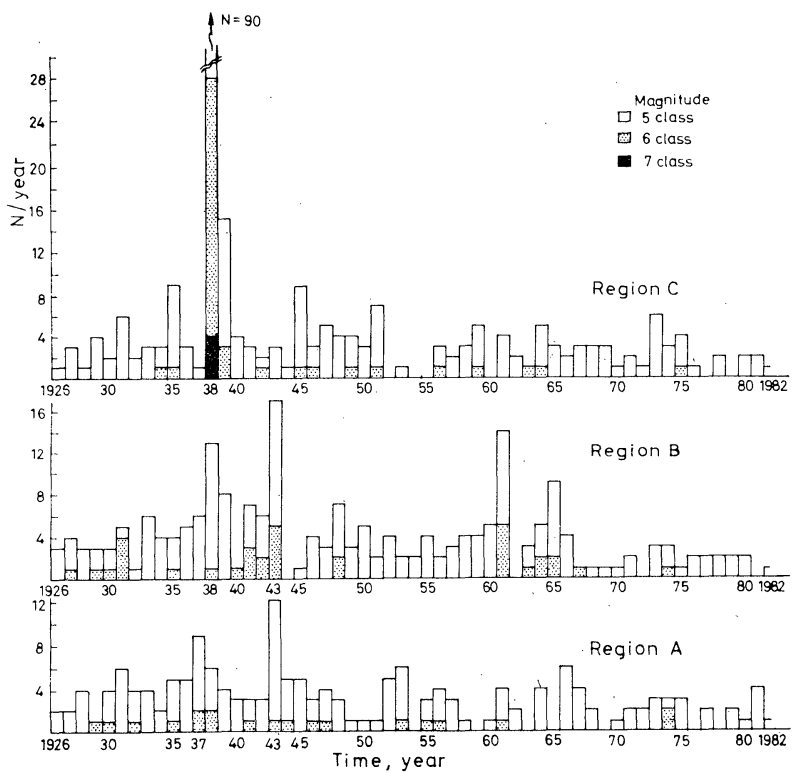

Fig. 2. Annual number of earthquakes with $M \geq 5$ and depth $\leq 60 \mathrm{~km}$.

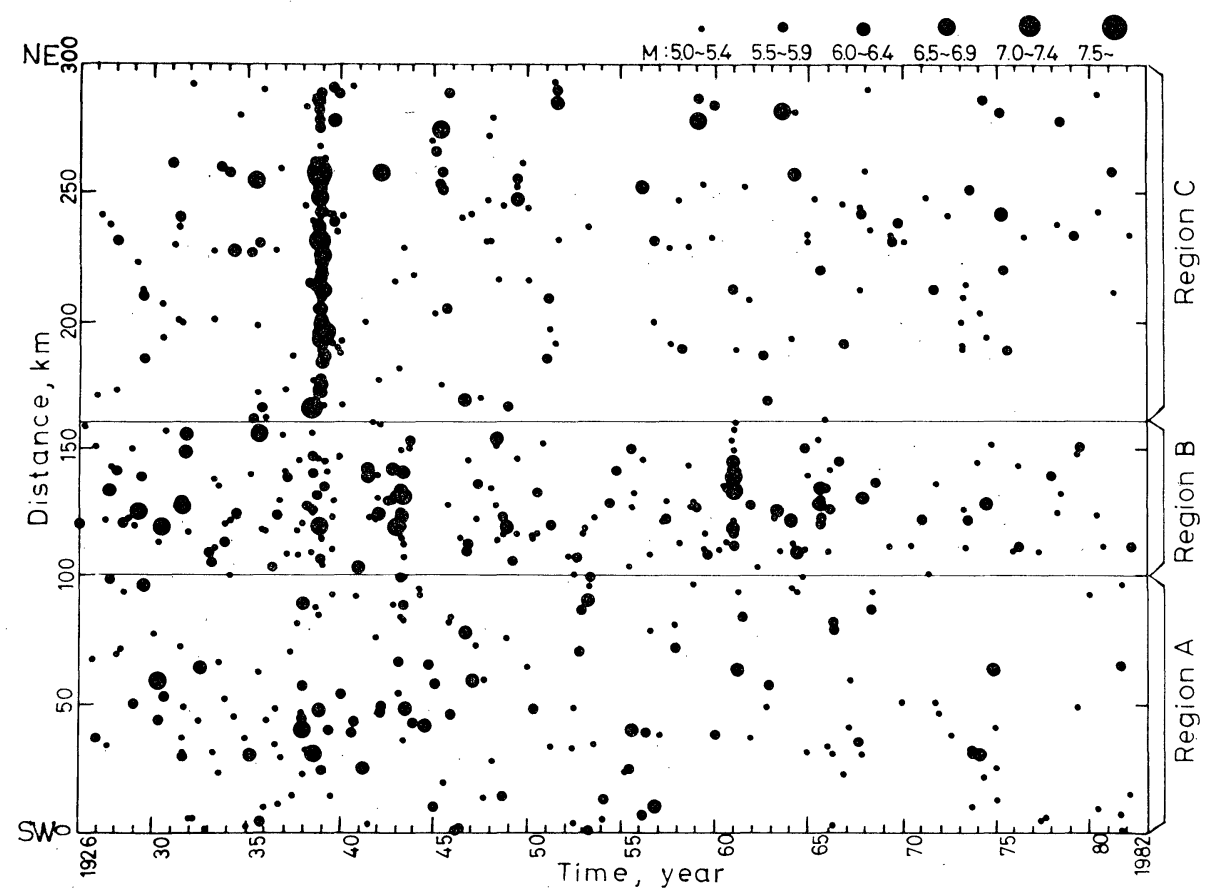

Fig. 3. Space-time plot of seismicity. Distances are measured northeastward along the trench axis from the southwestern boundary in Fig. 1. 
$M=7.0$ の地震までの約 2 年半は活動が極めて低い。また， 1931 年頃から福島沖の北側半分 の地域は地震活動が活発であるのに対して，南側では 1938 年まで空白部が目立つていること が特徴的である (Fig. 3). 次に, 茨城沖 (B 地域) では, 1931 年まで $M 6$ クラスの地震が続 き, その後 1935 年 7 月 19 日福島沖よりに 1926 年以降最大の $M=6.9$ が発生した. $1935 \sim$ 1937 年は, 福島沖の活動の低下とは対照的に $M 5$ クラスの活動が高い.さらに, 南隣の犬吠 岬周辺とその沖合にあたる A 地域でも 1937 年まで活動の増加傾向がみられる.

この 1935 1937 年の地震活動の様子を震央分布図として Fig. 4 に示す. 1938 年福島沖 群発地震の $M 7$ 以上の震央, およびこれらを含む主要な 8 個の地震により形成された総津波 波源域 [羽鳥 (1976) および ABE (1977) に基づく] も併せて示した. 大きな特徴は, 福島沖 の $1935 \sim 1937$ 年の地震が， 1938 年の $M 7$ クラスの震央执よび津波波源域の陸側よりの水深 200 500 m の海底下に列状に分布し，且つその多くは 1935 年（図中黒丸）に発生している ことである.また, 前述の 1935 年 7 月 19 日の $M 6.9$ は, 1938 年群発活動の端を発した 5 月 23 日の $M 7.0$ の震央付近に位置することも注目される. 1936, 1937 年福島沖は低調であ るのに対して, 南側の茨城沖と犬吠岬周辺ではこの期間活動が高い. また福島沖北隣でも, 1936 年 11 月 3 日 $M 7.5$ の金華山沖地震が発生し小津波を伴つている [例兄ば, 羽鳥 (1976)]. この, 福島沖における 1935 年の顕著な活動とその後約 2 年半の静穏化, 逆にこの間の周辺海 域での活発化という特徵は, 茂木 (1977) による広義の前震活動・ドーナッパタン現象に適合 する.

(2). 1938 年以降の地震活動をみると, 3 地域とも $M \geq 5$ の数は時間的な減少 傾向を示し, 特に最近 10 数年間の活動 の低下は著しい(Fig. 2). まず, 福島沖 北半分では, Fig. 3 に示されるように 1964 年まで $M 6$ クラスが活発であるが その後の活動は低い。な福島沖南より から茨城沖との境界にかけては，1976 年以降空白部が目立つ. 次に, 茨城沖で は, 1943 年 3,4 月（最大の地震 $M=$ 6.7 ), 1961 年 1 月（同 $M=6.8 ）$ そして 1965 年 9 月 (同 $M=6.7$ ) 顕著な群発地 震が発生している.これらの群発地震の 前の活動に着目すると，いずれもその $3 \sim 5$ 年位前から $M \geq 5$ の増加する傾向 がみられる (Fig. 2; Region B). しか し, 1982 年 7 月に発生した $M 7.0$ を 最大とするこの地域周辺では 1938 年以 来の大きな地震活動では, その前 15 年 程度の長期にわたつて活動が極めて低か つたことが特徴的である. 犬吠岬とその

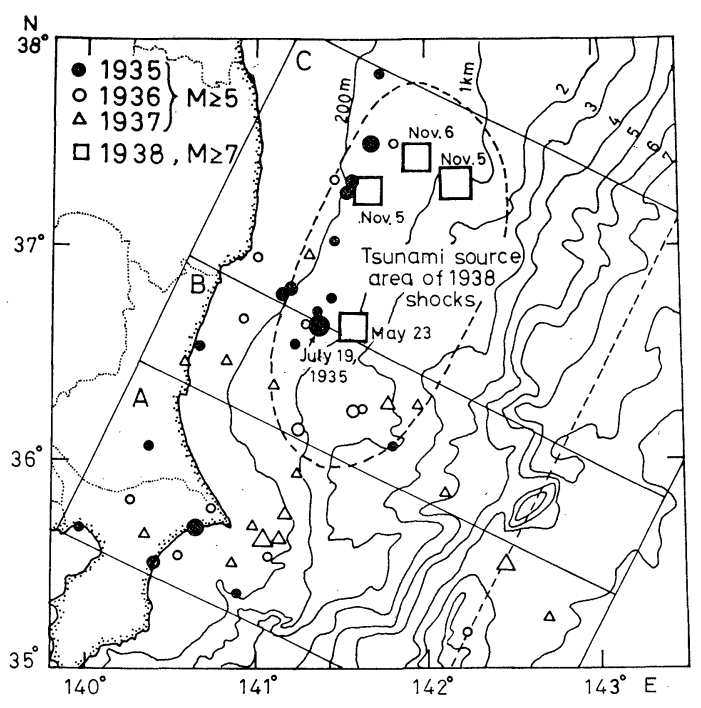

Fig. 4. Seismic activity for 1935-1937 $(M \geq 5)$ and in $1938(M \geq 7)$. Broken curve encircles the tsunami source area of the 1938 FukushimaOki earthquakes estimated for main eight events by Hatori (1976). Activity in 1935 around the landward margin of the tsunami source area is noticeable. 


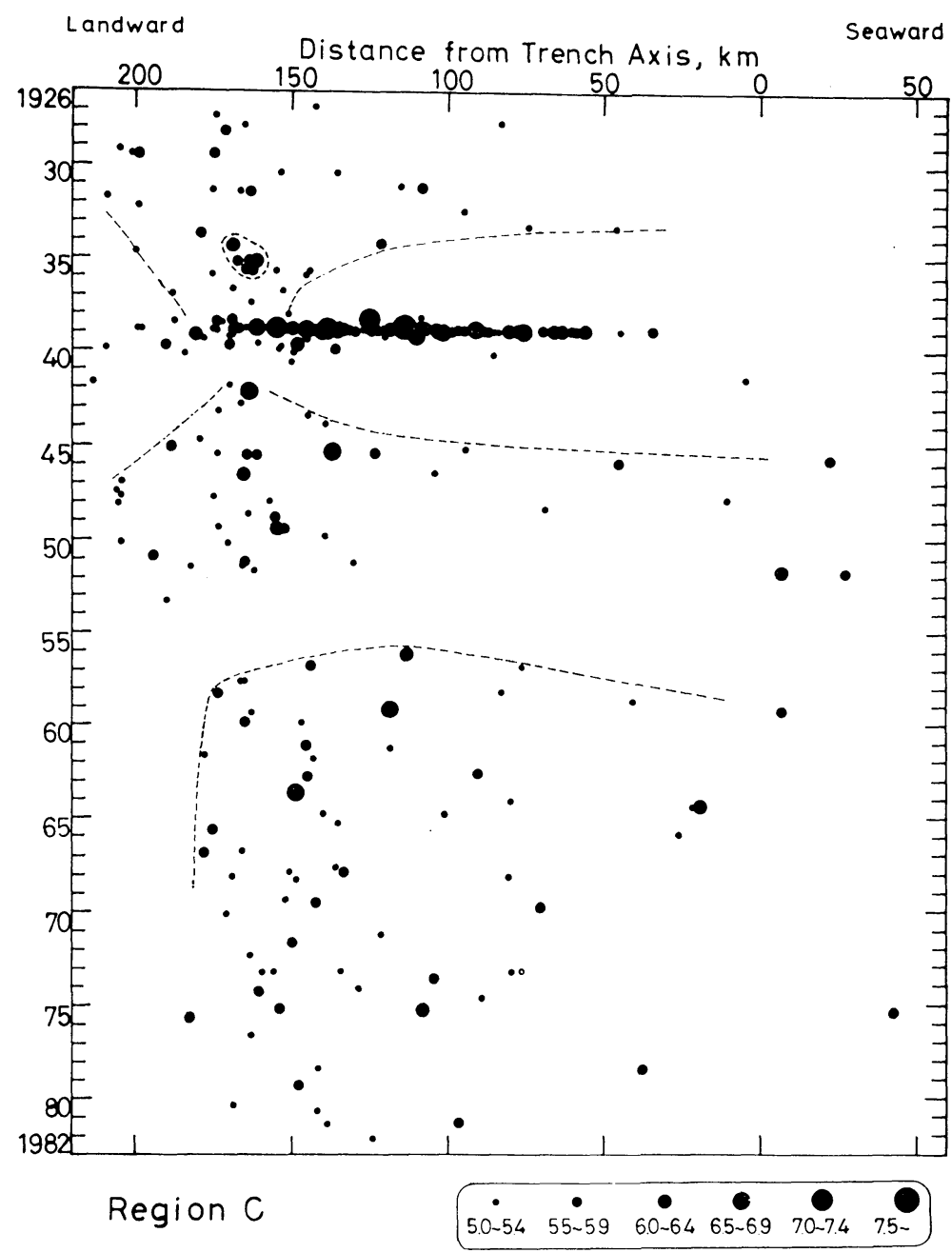

Fig. 5. Space-time plot of seismicity for the region $\mathrm{C}$ shown in Fig. 1. Distances are measured from the trench axis. Before the 1938 Fukushima-Oki earthquake series, distribution of foci shows the tendency to concentrate into a narrow zone, and after about 4 years the shocks, a spreading feature of foci can be seen. Activity in the landward portion is remarkably low in recent 30 years.

沖合でも，1940 年代半までは $M \geq 6$ を含む活発な活動がみられるが, 以後は全般に低調であ つて, 1976 年 1982 年 5 月は 3 地域とも $M 6$ 以上は発生していない.

以上の福島沖から房総半島東沖にかけての地震活動の諸特徵のうち, 特に福島沖の長期的な 活動の推移は, M8.1 の巨大地震に相当する 1938 年の群発地震 [辻・阿部 (1976)] のテクト ニクプロセスおよび応力場変動と密接に関係してい上う．この観点から，福島沖 (C 地域) の 活動を，Fig. 5 のように海溝軸直交方向の時空間分布上で眺めることにする. Fig. 5 から， 1938 年の群発地震の $4 \sim 5$ 年前から震源は陸寄りの限られた地帯へ徐々に集中し, 1935 年の 
活動は海溝軸から 160 170 km の所にかたまる様子がみられる.これを，この地帯への応力 集中による前駆的な破壞と考えると，その後 1938 年迄の静穏期は，この活動により平滑化さ れた応力レベルのさらなる上昇・プレート間の結合の強化を示唆する. 1938 年福島沖地震の らち主要な地震 8 個の発震機構の解析結果は, 海・陸プレート間のスラスト運動と海洋プレー ト内での正断層運動，およびその陸側部分の陸のプレートからの離脱・沈下の過程を物語る [ABE (1977)].ささらに，1938 年前後の地殼上下変動の詳細な解析によれば，太平洋側の陸地 は地震時震源域方向へ著しく傾斜・沈降したが，その後の回復地殼変動は 5 年ないしそれ以下 で収まつたことを示唆している [ABE (1977)]. Fig. 5 にみられるように 1938 年地震後 1941 年頃までは地震活動が低く，この回復地款変動は aseismic に進行したと考えられる. 1942 年 2 月 21 日の $M 6.5$ 以降 1951 年頃までの地震は, 1938 年前の活動集中域から陸側と海溝方向 へ広がる様子を示す. 1938 年地震の回復的変動が 5 年程度とすると, その後のこの広範囲の 活動は，プレート境界面での新たな結合の始まりとも考えられる. 1952〜1955 年は Fig. 5 の とおり著しい空白期間である. 1965 年以降は現在まで全般に低調で，特に海溝から約 $170 \mathrm{~km}$ 以遠, 海底地形で $200 \mathrm{~m}$ の等深度線よりも陸側の地帯に $M \geq 5$ はみられず，さらに $M \geq 6$ は海溝から $150 \mathrm{~km}$ より陸側にこの 30 数年間起きていない (1982 年 5 月現在).
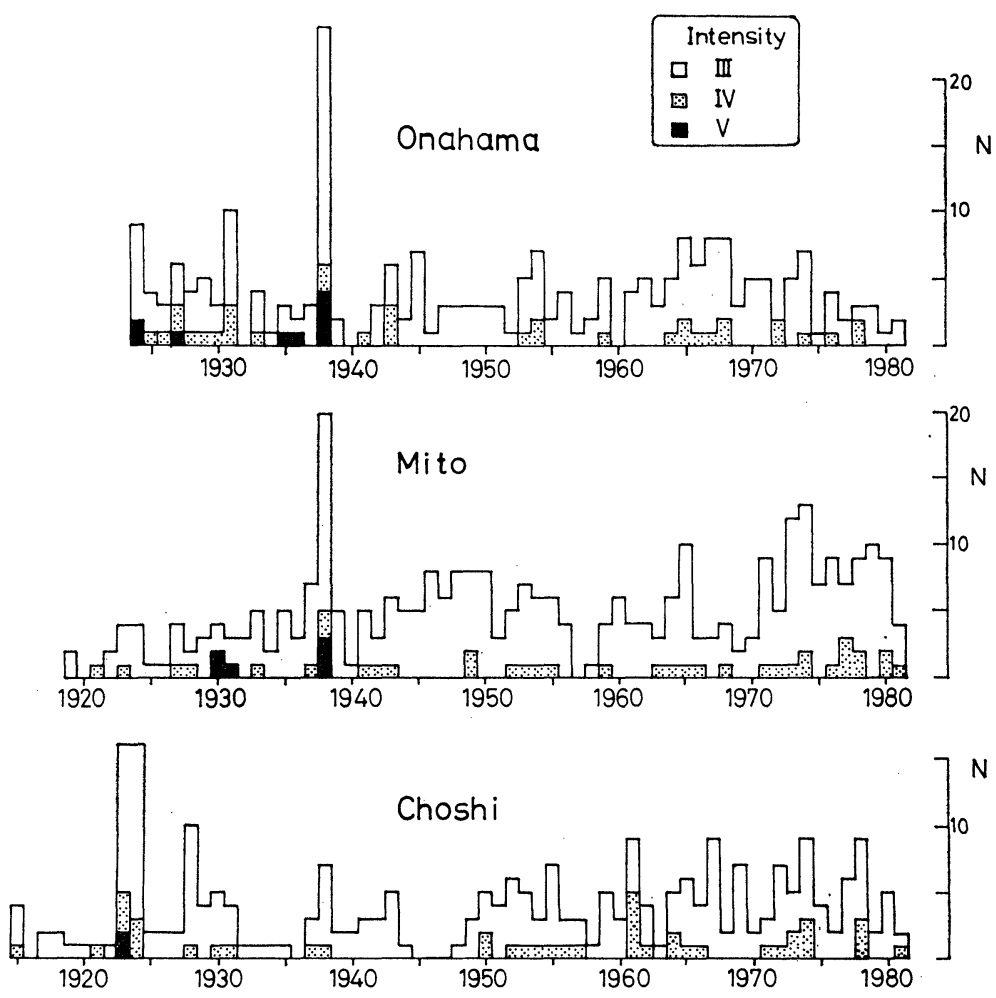

Fig. 6. Annual number of shocks with intensity III or over (JMA scale) observed at Onahama, Mito and Choshi, respectively. Location of the station is shown in Fig. 7. Data are taken from the JMA report. 
以上述ベた福島沖から房総半島東沖にかけての最近 10 数年間の全般的な活動の低下，およ び福島沖陸側部のより長期間の空白傾向はどのような応力場の変動を反映しているのであろう か. その推定のため, 次に震度の観測資料を用いて個々の地震の短周期と長周期地震動の相違 を定量的に求め, 震源域の力学的性質を調べる.

\section{§3. 震度観測資料と低周波・高周波地震の時間変化}

Fig. 6 は，太平洋岸の小名浜，水戸および銚子の三つの気象官署で観測された気象庁震度 階而以上の 1 年毎の頻度分布である. 資料は気象庁技術報告第 76 号 (1971) および地震月報 による. 各点の観測はほとんどその官署周辺の地震によるものと考兄られるが，震度の回数か ら地震活動をみる場合，震度判定に影響する諸要素を充分考慮する必要がある．岡田 (1978) による東北・北海道太平洋岸気象官署の有感地震回数の時間変化の調査によれば，銚子では 1949 年 9 月海岸ふらから市街地への官署移転のため, 以後有感回数の系統的な増加が見出さ れている. Fig. 6 の銚子における震度 III 以上の分布でも 1950 年前と後とで資料の質は異な ると考えられる.小名浜では，1979 年 1 月同じ場所で新庁舎へ移転したとのことであるが， 震度観測への影響は移転後の期間が短いため不明である. 水戸では大幅な移転等はないとのこ とである.

Fig. 6 で, 震度 V は水戸と小名浜では 1938 年以降, 銚子では 1923 年以降長期間観測さ れていない，最近の変化をみると，小名浜では 1965１968 年に活動の山を持つがその後は減 少傾向を示す. 一方, 水戸では 1970 1974 年にかけて震度而以上の増加がみられ, 最近 10 年 間の回数はその前 10 年間の約 2 倍である. 銚子においても，1950 年代後半から 1960 年代始 めにかけて増加傾向がみられる. 前述のように, これら観測点沖合の福島沖から房総半島東沖 にかけては最近 10 数年以上 $M \geq 5$ の活動の低下が著しい.これらのことから, 特に茨城沖 の 1976 年頃からの $M \geq 5$ の減少と, 水戸における震度 III 以上の 1970 年代前半からの増加 傾向とは，極めて対照的で特異な観測結果といえる，有感震度は，人体に敏感な周波数 1 5 サイクル程度の地震動の大きさを表わし, 一方, $M 5$ 程度以上の気象庁マグニチュードは, 地 震月報の調查によると周期 3 4 秒の最大地動振幅から決められている [NOGUCHI (1979); KOYAMA et al. (1979)]. したがつて, 上述の震度とマグニチュードでみた場合の活動度の時 間的相違は, ふたつのかけ離れた周波数帯域の震源スペクトル密度の関係が地震により異なる ためと考えられる．断層運動の違いが震源スペクトルの違いに表われ，したがって異なった周 期のマグニチュードの関係に反映されることは, 観測と理論の両面から確められている [例之 ば, 野ロ・阿部 (1977)]. この観点から, 震度に基づくマグニチュードを決定し気象庁マグニ チュードとの比較を行い, 震源過程の違いを推察する.

震度による規模決定は, 例えば, UTSU (1961，1980), 村松 (1969), 勝又・徳永 (1971) で扱 われているが，ここでは限られた領域の $M 5$ クラスを含めた地震を対象とするため，震源域 近辺の観測值を利用し，河角の方法 [河角 (1943) および KAWASUMI (1951)] を用いる. 河角 マグニチュード $M_{K}$ と気象庁震度階 $I$ との関係は, 震央距離 $100 \mathrm{~km}$ 以上と末満について求 められているが，それらは，元の式を整理しなおした宮村（1974）の表現に従らと，各々次の ように表わされる。

$$
M_{K}=I+0.00183(\Delta-100)-9.2104+4.6052 \log \Delta ; \quad \Delta \geq 100 \mathrm{~km}
$$




$$
\begin{aligned}
M_{K}=I & +2\left(\log \sqrt{h^{2}+\Delta^{2}}-\log \sqrt{h^{2}+(100)^{2}}\right) \\
& +0.0617\left(\sqrt{h^{2}+\Delta^{2}}-\log \sqrt{h^{2}+(100)^{2}}\right) ; \quad \Delta<100 \mathrm{~km}
\end{aligned}
$$

ここに $h$ は震源の深さ $(\mathrm{km}), \Delta$ は震央 距離 $(\mathrm{km})$ である.[なお，宮村 (1974)

にあるように, KAWASUMI (1951) の (9) 式右辺第 3 項の符号 +は一の誤植であ る].ささらに, KAWASUMI (1951) によれ ば， $M_{K}$ から通常の規模を得るための変 換式は次のように与えられる。

$$
M_{I}=4.85+0.5 M_{K}
$$

ここで $M_{I}$ は $M$ と同等のマグニチュ ードである. (1)，(2) および (3) 式を用 いて震度観測值からマグニチュードが決 定される.

$M_{I}$ 決定のため, Fig. 7 のように太 平洋岸沖の $35^{\circ} \sim 38^{\circ} \mathrm{N}$ の三つの地域 I, II , III を取り, 地震月報の発刊 (1951 年) 以降 1982 年 5 月までの $M 5$ 以上深さ $60 \mathrm{~km}$ 以浅の地震について, 各地域近

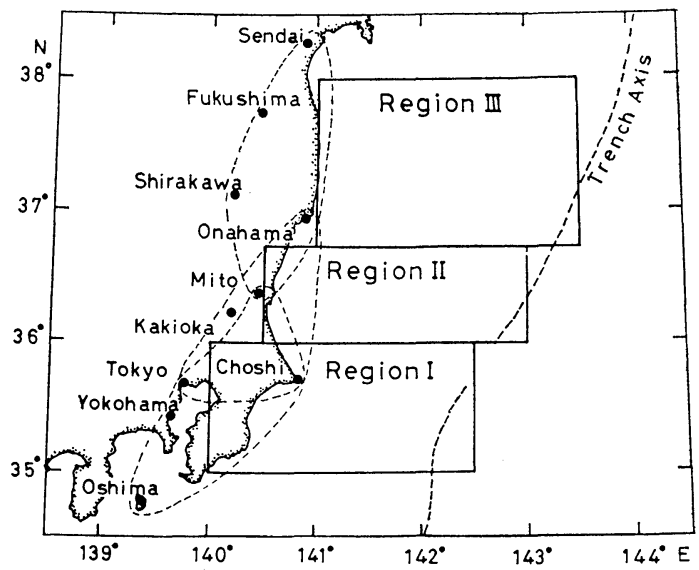

Fig. 7. Location of stations at which seismic intensity data are investigated. For earthquakes occurring in the three rectangular regions, felt intensity data obtained at respective neaby five stations enclosed by broken line are used to determine magnitude $M_{I}$ through Kawasumi's $(1943,1951)$ formula.

Table 1. Examples of determination of $M_{I}$ for two earthquakes off Ibaraki Prefecture. $M_{K}$ : Kawasumi's $(1943,1951)$ magnitude. Epicenter, depth and $M$ are based on JMA reports.

July $11,1970,23: 28,36.50^{\circ} \mathrm{N}, 140.58^{\circ} \mathrm{E}$, Dep. $=50 \mathrm{~km}, M=5.1$

\begin{tabular}{lcccc}
\hline \hline Station & $\Delta(\mathrm{km})$ & Intensity & $M_{\boldsymbol{K}}$ & $M_{\boldsymbol{I}}$ \\
\hline Mito & 17 & 2 & 0.36 & 5.03 \\
Kakioka & 46 & 3 & 1.70 & 5.77 \\
Onahama & 57 & 3 & 2.06 & 5.88 \\
Choshi & 89 & 2 & 1.76 & 5.73 \\
Tokyo & 117 & 1 & 1.34 & 5.52 \\
\hline Average & & & & $5.59 \pm 0.34$ \\
\hline
\end{tabular}

April $19,1977,15: 15,36.47^{\circ} \mathrm{N}, 140.62^{\circ} \mathrm{E}$, Dep. $=60 \mathrm{~km}, M=5.1$

\begin{tabular}{lcccc}
\hline Station & $\Delta(\mathrm{km})$ & Intensity & $M_{\boldsymbol{K}}$ & $M_{\boldsymbol{I}}$ \\
\hline Mito & 16 & 4 & 2.54 & 6.12 \\
Kakioka & 46 & 3 & 1.94 & 5.82 \\
Onahama & 59 & 2 & 1.18 & 5.44 \\
Choshi & 85 & 3 & 2.68 & 6.19 \\
Tokyo & 116 & 2 & 2.32 & 6.01 \\
\hline Average & & & $5.92 \pm 0.30$ \\
\hline
\end{tabular}


傍に位置する気象官署 $\mathbf{5}$ 力所の震度報告値を調べた。そのうち，3 カ所以上で有感（震度 I 以 上）であつた地震の震度から上記 (1)，(2) および (3) 式を用いて各官署毎の $M_{I}$ を求め, さ らにそれらの平均を取つて $M_{I}$ を決定した，茨城沖のふたつの地震（ともに $M=5.1 ） の M_{I}$ 決定例を Table 1 に示す. このようにして, Fig. 7 の対象地域の $M 5$ 以上深さ $60 \mathrm{~km}$ 以 浅の地震 245 個のらち 191 個の $M_{I}$ が決定された。このらち, 各地域 $\mathbf{5}$ 力所の官署の有感震 度から決められたものが $68 \%$ ， 4 カ所が $20 \%, 3$ カ所が $12 \%$ である. また，五つの官署で まつたく無感または震度報告值のない地震は 21 個であつた。震度といら粗い量のため, 官署 毎の $M_{I}$ が相当ばらつくものもあるが, 標準偏差 \pm 0.4 以内の地震は全体の $78 \%$ である.

Fig. 8 は，上述の方法で決められた $M_{I}$ と $M$ の関係を示す. 全体として $M_{I}$ と $M$ は 比例関係にあるが, その勾配 $M_{I} / M$ は各地域とも 1 より小さく, 規模が大きくなると $M_{I}$ は $M$ に近づく傾向を持つ. また，どの地域も $M_{I}$ は $M$ よりも系統的に大きく, $M_{I}-M$ の平均 は図中のような值となる．河角方式による地震の規模が通常の $M$ よりも過大となることは, これまでの調査結果 [TSUBOI (1964)；宇佐美・茅野 (1970)] と調和する. 3 地域を比較すると， 特に地域 III は地域 I, II より $M_{I}-M$ が系統的に大きい.この原因として, 観測点下の地盤 特性や震源・観測点間の波動伝播特性の地域的相違が考えられる. また, 地域 III の $M_{I}$ 決定 に用いた気象官署は比較的広範囲に分布し, 同じ震度域でも震央距離が長いため相対的に大き な $M_{I}$ となることも推察される. さらに, 地域 III の地震の震源スペクトルそのものが地域 I, II よりも短周期成分に富むことも考えられるが，そのためには広い周波数範囲での地震記象 の比較・検証が必要となる. 以上のような全体的特徵に対して, 個々の地震間の $M_{I}$ 対 $M$ を 比較すると, 例えば同じ $M$ に対して $M_{I}$ が相互に著しく異なるものがある. これは, 震源 過程の力学的性質の違いを反映しているためと考えられる.

Fig. 9 は, 各々の地域の $M_{I}$ と $M$ の差の時間分布を示す. いくつかの期間の $M_{I}-M$ の 平均値および発生順 5 個毎に取つた移動平均の曲線も示してある. 個々の地震の $M_{I}-M$ のば らつきの幅はかなりのものである. しかし全期間を通してみると, 各地域とも $M_{I}-M$ が時間 とともに増大する，すなわち周期数秒の地震動に対してそれより 1 オーダー短周期の地震動が 時間的に大きくなる傾向が認められる。福島沖の地域 III では 1965 年頃から $M_{I}-M$ の系統的 な上昇傾向がみられ, 地域 II でも, 1961 年と 1965 年の群発活動によつて $M_{I}-M$ は一時的

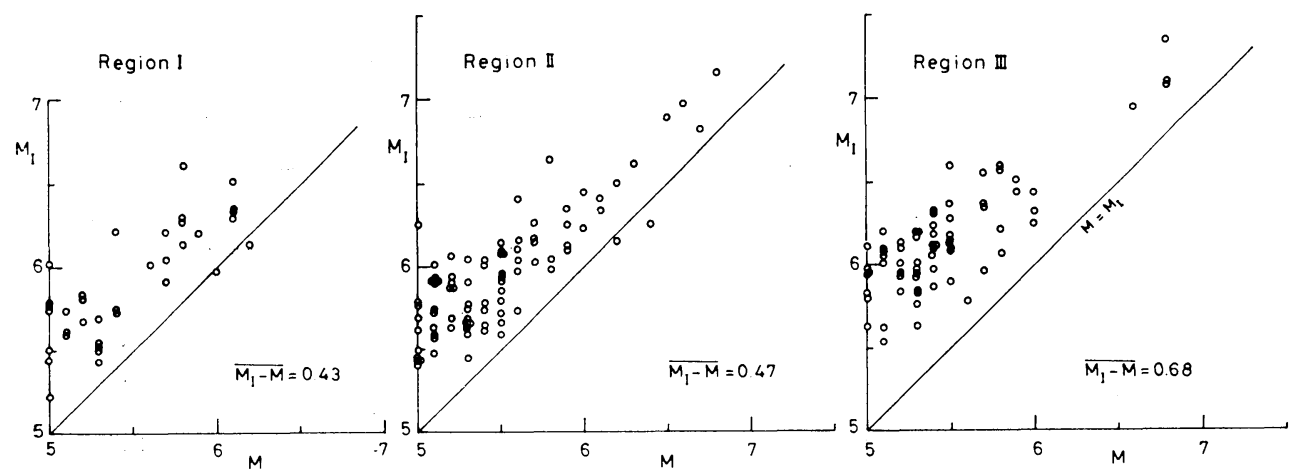

Fig. 8. Relation between $M_{I}$ determined from seismic intensity data and $M$ reported by JMA. 

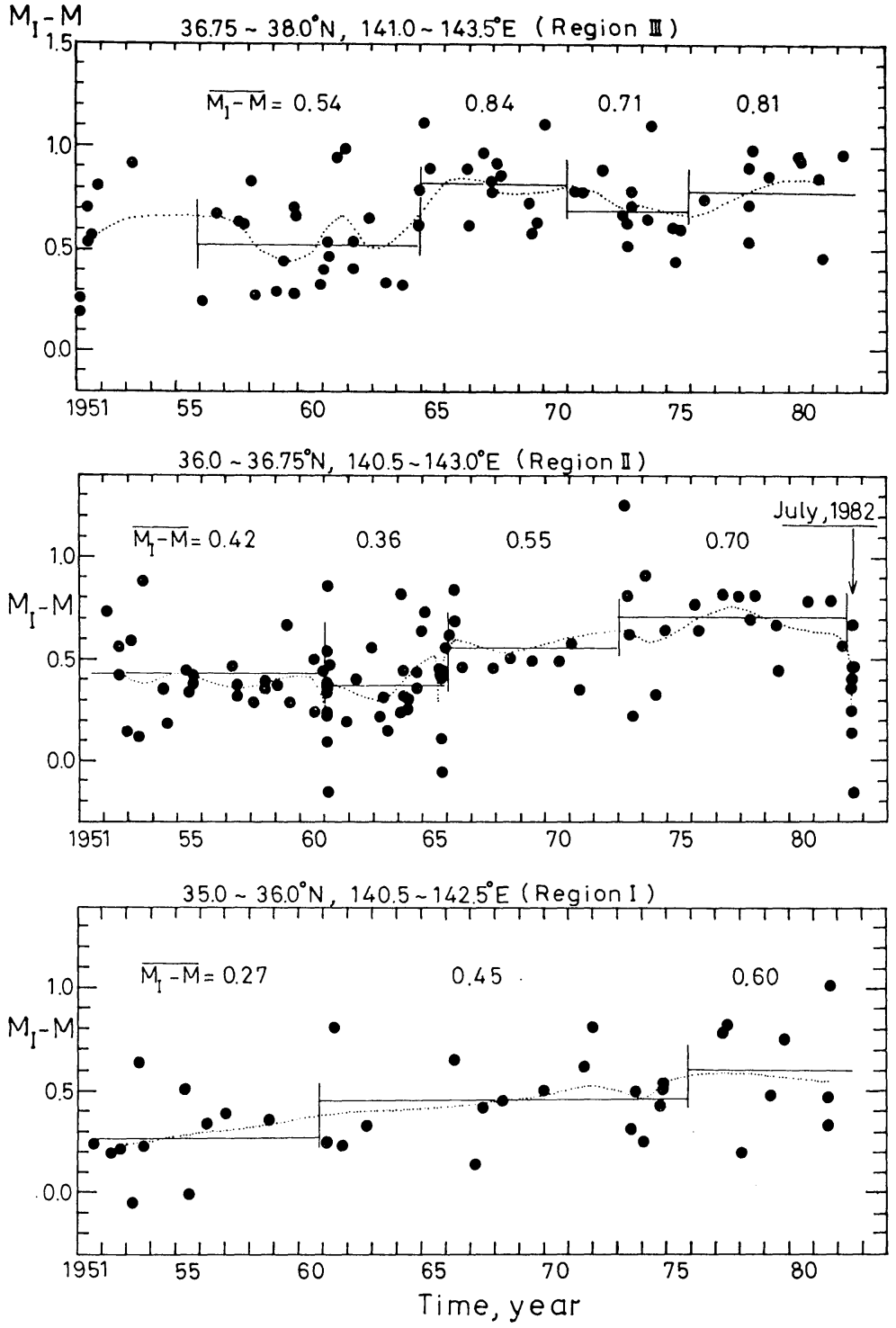

Fig. 9. Temporal variation of the difference between $M_{I}$ and $M$. Numerals show the average of the $M_{I}-M$ for the corresponding periods, and dotted curve the running average through succesive five points.

に減少しているが，その後 1982 年 7 月の $M 7.0$ を最大とする地震活動まで $M_{I}-M$ の大き な地震がそろつている. 1982 年 7 月の $M_{I}-M$ は気象庁地震火山概況の暫定資料に基づくが， $M_{I}-M$ は小さいものが多く低周波性を示す. 地域 III でも $M_{I}-M$ は徐々に大きくなる 傾向が 明瞭である.このような特徴は, UTSU (1980) による $M \geq 6$ の地震の解析結果と調和する.

Fig. 9 で地域 II および I の $M_{I}-M$ の時間変化は, 各々 Fig. 6 の水戸と銚子の震度 III 以 
上の回数の年変化と大体対応している. これに対して, 地域 III $M_{I}-M$ は 1975 年頃から増 大気味であるが, Fig. 6 の小名浜では 1968 年以降震度 III 以上の回数は減少傾向にあり, 水 戸と地域 II, 銚子と地域 I の対応関係とは異なる。こ水は, 小名浜に近い福島沖南半分と茨城 沖北よりの地域で 1968 年頃から空白が目立ち (Fig. 3), 小名浜の震度 III 以上の減少は主にこ の地域の地震活動の低下を表わし, 一方最近の $M_{I}-M$ の増加は主に福島沖北半分の地震によ るものであることを示している.

Fig. 9 に打いて， $M_{I}-M$ が各々の地域の全期間にわたる平均値よりも大きい，すなわち相 対的に短周期動の卓越する地震のうち，1972 1982 年 5 月の地震の震央分布を Fig. 10 に示 す.むた， 1982 年 7 月の茨城沖の活動の震源域と最大地震の震央も図中に示した。高周波地 震は, これまでの解析結果 [FUKAO and KANJO (1980); UTSU (1980)] のように陸寄りの大

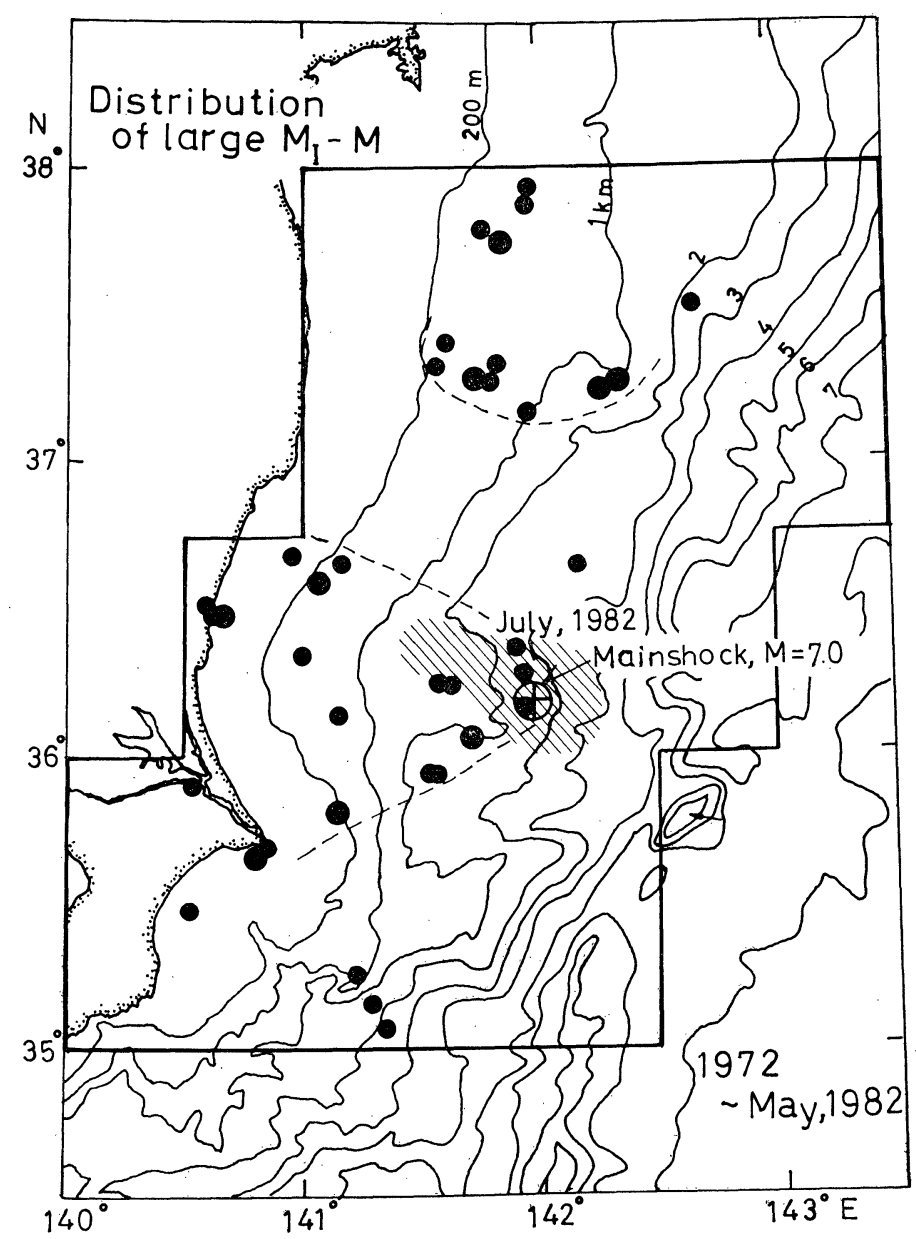

Fig. 10. Distribution of earthquakes of large $M_{I}-M$ for the period from 1972 to May 1982. The mainshock (circle with cross) and focal zone (shaded area) of the Ibaraki-Oki earthquake of July 1982 are also shown. 
陸棚斜面下に比較的多く分布している.ささらに Fig. 10 では, 1982 年 7 月の最大地震の震央 付近から鹿島灘，犬吠岬方向へ放射状の分布傾向がみられる。また，福島沖では，北上りの 1938 年 11 月の $M 7$ クラスの地震の震央付近 (Fig. 4)に数多く集中していることが注目さ れる.

\section{§4. 考察}

前節の $M_{I}$ 決定は，震度という粗い量に基づいており，また震央距離 $100 \mathrm{~km}$ 以上の (1) 式と $100 \mathrm{~km}$ 未満の (2) 式とでは $M_{I}$ は必ずしも同一の值とはならない[宮村 1974)]. した がつて, $M_{I}-M$ の值はある程度誤差を伴い, 個々の地震間の $M_{I}-M$ の差は複雑な震源過程 の第一近似的な相違を示す尺度である. しかし，これらのことを考慮しても，前節の解析で得 られた長期間の多数の地震の $M_{I}-M$ の系統的な時間変化と地域的な分布の特徵は, 地震発生 に関係した応力場の変動をかなり良く反咉したものと考兄られる.

Fig. 10 で, 福島沖南半分と $200 \mathrm{~m}$ の等深度線より陸側部分では $M_{I}-M$ の大きな地震は みられない。もともと，この陸側部分は，1952 年頃から長期間 $M \geq 5$ の地震の空白域である (Fig. 5)。また, 福島沖南部から茨城沖よりの海域も 1965 年頃から空白が目立つている (Fig. 3). 福島沖南半部の空白傾向は, 1938 年の大地震の前にもみられ (Fig. 3), 1935 年に前兆的 活動が震源域の陸よりに集中した。最近, 大地震に至る地震活動パタンを媒質内の応力や昰の 時間変化，破壊強度分布の仮定などから合理的に説明する試みがなされている[茂木 (1977); Mikumo and Miyatake (1979); 津村 (1979); Katsumata and Yoshida (1980); 金森 (1980)]. 福島沖南部と陸側部の $M \geq 5$ の空白は, この地域の破壊強度が平均的に現在の応力 レベルよりも高く，金森（1980）のモデルによるアスペリティへの応力集中が依然続いている ためと解釈できる．またこれは，KATSUMATA and YoSHIDA (1980) のプレート境界大地震の 震源域生成過程のうち，「震源域の核」の形成段階に相当するとも考元られる[勝又 ・ 山本 (1982)].

一方, 福島沖北半分および茨城沖には, Fig. 10 のように $M_{I}-M$ の大きな地震がみられ, 時間的には 1965 年ないし 1966 年頃からである (Fig. 9). KAWAKATSU and SENO (1983) は, 福島沖から茨城沖にかけて,アサイスミクフロントの海側で二重深発地震面の上面よりも浅部 にスラスト型の地震を多数見出し，これはこの地帯の応力増強によるためと解釈している．彼 らの示したスラスト型地震の震央分布は, おおまかに Fig. 10 の $M_{I}-M$ の大きな地震の分布 と対応する. これらのことから，1965 年頃からの高周波地震の卓越傾向は, 海・陸プレート の結合の強化によるこの頃からの広域的な応力増大と強度の高い断層近傍への応力集中による ためと考えられる.

茨城沖に発生した 1982 年 7 月 23 日の $M 7.0$ の地震は, 海溝寄りの水深 $2,000 \sim 3,000 \mathrm{~m}$ の急崖下に位置し, その後余震は徐々に陸側に拡がり, 全体として海溝から陸方向への細長い 震源域を形成した [岡田・他 (1982); 気象庁地震予知情報課 (1983); MIZOUE et al. (1983); 東 北大学理学部 (1983)]. 茨城沖は, 複雑な地形変化と対応して, 周辺海域に比べ海溝付近まで 破砕度が高く [MOGI (1967)], したがつて断層強度の分布のばらつきも大きいと考兄られる. このため, 広域的に応力が増加しても強度の高い空間的に一様なアスペリティの形成はむずか しく，広範囲に徐々に短周期に富む地震が発生するようになる (Fig. 9 の Region II, Fig. 
10) が，際立つた空白域・空白期間は現われず (Fig. 2 の Region B, Fig. 3) 今回のような 破壊に至つたと解釈される.

以上のように，福島沖から房総半島沖にかけての海域は，現在，強く圧縮された $M \geq 5$ の 地震空白域と，短周期動に富む地震が発生する小規模のアスペリティの集合域から形成され， これはこれら海域全体にわたる広域的な応力レベルの上昇によるものと考えられる。この過程 で 1982 年 7 月の茨城沖地震が発生したが, これにより隣接海域で応力がさらに増大し, 今後 大規模な破壊に至ることも推察可能である. したがつて, $M \geq 5$ の地震の空白域での $M 5,6$ クラスの地震の発生や微小地震の顕著な增加, また $M_{I}-M$ のさらなる增加等には注意を要す る.また，海・陸プレートの結合が強まれば，陸側プレート内での歪蓄積も予想され，内陸部 の地震活動にも注目すべきと思われる.

\section{謝辞}

本研究に際し，適切な御指示と有益な御助言をいただいた国立防㷋科学技術センタ一第 2 研 究部の大竹政和氏，岡田義光氏，笠原敬司氏，江口孝雄氏はじめ，第 2 研究部の皆様に深く感 謝致します.

\section{文献}

ABE, K., 1977, Tectonic Implication of the Large Shioya-Oki Earthquakes of 1938, Tectonophysics, 41, 269-289.

ABE, K. and H. Kanamori, 1979, Temporal Variation of the Activity of Intermediate and Deep Focus Earthquakes, J. Geophys. Res., 84, 3589-3595.

ABE, K. and H. Kanamori, 1980, Magnitudes of Great Shallow Earthquakes from 1953 to 1977, Tectonophysics, 62, 191-203.

FUKAO, Y. and K. Kanjo, 1980, A Zone of Low-Frequency Earthquakes beneath the Inner Wall of the Japan Trench, Tectonophysics, 67, 153-162.

Geller, R.J. and H. KaNAmori, 1977, Magnitudes of Great Shallow Earthquakes from 1904 to 1952, Bull. Seism. Soc. Am., 67, 587-598.

浜田和郎・大竹政和 ・岡田義光・松村正三・山水 史生・佐藤 春夫 ・井元政二郎 ・立川真理子・大久保 正・山本英二・石田瑞穂・笠原敬司・勝山ヨシ子・高橋 博, 1982 , 関東・東海地域地殼活動観 測網一一国立防災科学技術センター, 地震 $2,35,401-426$.

羽鳥徳太郎, 1976, 1938 年福島沖群発地震による津波の発生機構, 地震 2, 29, 179-190.

井上宇胤，1965，新潟地震前における震央付近及び隣接地域の地震活動について，験震時報，29，139144 .

金森博雄, 1980 , 地震活動と地震予知——南カリフォルニアの例——, 地震予知研究シンポジウム (1980), 163-174.

加藤昌典・山崎謙介・池上良平， 1981 , 東北日本の太平洋岸沖における地震活動の時間的変化，地震 $2,34,323-339$.

勝又 護・徳永規一, 1971, 震度 IV の範囲と地震の規模および震度と加速度の対応, 験震時報, 36, 89-96.

Katsumata, M. and A. Yoshida, 1980, Change in Seismicity and Development of the Focal Region, Papers in Meteorology and Geophysics, 31, 15-32.

勝又 護・山本雅博, 1982, 福島県沖の “空白域” について, 地震学会講演予稿集, No. 1, 58.

Kawakatsu, H. and T. Seno, 1983, Triple Seismic Zone and the Regional Variation of Seismicity along the Northern Honshu Arc, J. Geophys. Res., 88, 4215-4230.

河角 広, 1943, 震度と震度階, 地震 $1,15,6-12$.

Kawasumi, H., 1951, Measures of Earthquake Danger and Expectancy of Maximum Intensity 
Throughout Japan as Inferred from the Seismic Activity in Historical Times, Bull. Earthq.

Res. Inst., 21, 469-482.

気象庁, 1966, 日本付近の主要地震の表 (1957 年 1962 年), 地震月報別冊 $2,49 \mathrm{pp}$.

気象庁, 1968, 日本付近の主要地震の表 (1963 年 1967 年), 地震月報別冊 $3,62 \mathrm{pp}$.

気象庁, 1971 , 日本における震度観測の記録, 気象庁技術報告第 76 号, $222 \mathrm{pp}$.

気象庁，1982，改訂日本付近の主要地震の表 (1926 年 1960 年), 地震月報別冊 $6,109 \mathrm{pp}$.

気象庁地震予知情報課，1983，1982 年 7 月 23 日茨城県沖の地震, 地震予知連絡会会報, 29， 89-95.

Koyama, J., M. Takemura, and Z. Suzuki, 1979, Seismic-Moment Determination Qualified for Routine Processing of Seismic Data, Sci. Rep. Tohoku Univ., Ser. 5, 26, 81-91.

Mikumo, T. and T. Mryatake, 1979, Earthquake Sequences on a Frictional Fault Model with Non-Uniform Strengths and Relaxation Times, Geophys. J.R. Astr. Soc., 59, 497-522.

宮村攝三, 1974, 地震時における原子力施設の限界設計に関する試験研究, 昭和 47 年度成果報告 (日 本電気協会), 42-80.

Mizoue, M., I. Nakamura, H. Chiba, M. Yoshida, H. Hagiwara, and T. Yokota, 1983, Westward Movement of the Seismic Activity Associated with the Earthquake of July 23, 1982 off Ibaraki Prefecture, Northeastern Honshu, Japan, Bull. Earthq. Res. Inst., 58, 2563.

茂木昭夫・荻野卓司・大島章一，1980，鹿島灘沖の海底地形，地質構造，地磁気全磁力について，地 震予知連絡会会報, 23，29-31.

茂木昭夫・西沢邦和，1980，日本海溝に打ける第 1 鹿島海山の崩壊，地震予知連絡会会報，24，70-72.

MOGI, K., 1967, Regional Variation of Aftershock Activity, Bull. Earthq. Res. Inst., 45, 711726.

茂木清夫, 1977, 地震活動と地震予知, 地震予知研究シンポジゥム (1976), 203-214.

茂木清夫, 1979, 東日本の最近の地震活動について, 地震予知連絡会会報, 21, 140-141.

村松郁栄, 1969, 震度分布と地震のマグニチニードの関係, 岐阜大学教育学部研究報告——自然科学, $4,168-176$.

NoGUCHI, S., 1979, On the Relation between Surface-Wave Magnitude and JMA Magnitude, J. Fac. Sci. Hokkaido Univ., Ser. VII, 6, 213-224.

野口伸一, 1982, 茨城県東沖地震の規模別時間間隔について, 地震学会講演予稿集, No. 1, 59.

野口伸一・阿部勝征, 1977, 地震の発生機構と $M_{s}-m_{b}$ 関係, 地震 2, 30, 487-507.

岡田 弘，1978，巨大地震に先立つ定常地震活動の低下一離れた大地震でトりガーされた例，北海 道大学地球物理学研究報告, 37, 43-51.

岡田義光・野口伸一・鵜川元雄・井元政二郎・大竹政和, 1982, 茨城県沖の地震 (1982 年 7 月 23 日) 概報, 国立防災科学技術センター研究速報, 46, 1-14.

SEno, T. and T. EGUCHI, 1983, Seismotectonics of the Western Pacific Region, AGU/GSA Geodynamic Series, Western Pacific Volume, in press.

Tamaki, K., Y. Inouchi, F. Murakami and E. Honza, 1977, Continuous Seismic Reflection Profiling Survey, in Geological Investigation of Japan and Southern Kurile Trench Slope Areas GH 76-2 Cruise April-June 1976, Cruise Report No. 7, edited by E. HonZA, Geological Survey of Japan, 50-71.

東北大学理学部，1983，1982 年 7月 23 日茨城沖に発生した地震, 地震予知連絡会会報, 29, 71-79.

Tsubor, C., 1964, Time Rate of Energy Release by Earthquakes in and near Japan-Its General Uniformity and Variability, J. Phys. Earth, 12, 25-36.

辻 秀昭・阿部勝征, 1976, 1938 年塩屋沖地震のマグニチュードとその付近のサイスミシティ, 地震 学会講演予稿集, No. $1,24$.

津村建四郎， 1979，地震活動および前兆現象の経過を説明するための一つの仮説，地震学会講演予稿 集, No. 1,159 .

宇佐美龍夫・茅野一郎，1970，河角の規模と気象庁の規模との関保，地震研究所彙報，48，923-933.

UtSu, T., 1961, A Statistical Study on the Occurrence of Aftershocks, Geophys. Mag., 30, $521-605$.

Utsu, T., 1974, Space-Time Pattern of Large Earthquakes Occurring off the Pacific Coast of the Japanese Islands, J. Phys. Earth, 22, 325-342. 
宇津徳治, $1979,1885-1925$ 年の日本の地震活動— $M 6$ 以上の地震および被害地震の再調查—, 地震研究所彙報, 54, 253-308.

UTSU, T., 1980, Spatial and Temporal Distribution of Low-Frequency Earthquakes in Japan, J. Phys. Earth, 28, 361-384. 